\title{
GLUCOSE(XYLOSE) ISOMERASE PRODUCTION BY STREPTOMYCES SP. CH7 GROWN ON AGRICULTURAL RESIDUES
}

\section{Kankiya Chanitnun, Pairoh Pinphanichakarn*}

Department of Microbiology, Faculty of Science, Chulalongkorn University, Bangkok 10330, Thailand.

Submitted: November 03, 2010; Approved: June 07, 2012.

\begin{abstract}
Streptomyces sp. CH7 was found to efficiently produce glucose(xylose) isomerase when grown on either xylan or agricultural residues. This strain produced a glucose(xylose) isomerase activity of roughly $1.8 \mathrm{U} / \mathrm{mg}$ of protein when it was grown in medium containing $1 \%$ xylose as a carbon source. Maximal enzymatic activities of about 5 and $3 \mathrm{U} / \mathrm{mg}$ were obtained when $1 \%$ xylan and $2.5 \%$ corn husks were used, respectively. The enzyme was purified from a mycelial extract to 16-fold purity with only two consecutive column chromatography steps using Macro-prep DEAE and Sephacryl-300, respectively. The approximate molecular weight of the purified enzyme is $170 \mathrm{kDa}$, and it has four identical subunits of $43.6 \mathrm{kDa}$ as estimated by SDSPAGE. Its $K_{\mathrm{m}}$ values for glucose and xylose were found to be 258.96 and $82.77 \mathrm{mM}$, respectively, and its $V_{\max }$ values are 32.42 and $63.64 \mu \mathrm{M} / \mathrm{min} / \mathrm{mg}$, respectively. The purified enzyme is optimally active at $85^{\circ} \mathrm{C}$ and $\mathrm{pH}$ 7.0. It is stable at $\mathrm{pH} 5.5-8.5$ and at temperatures up to $60^{\circ} \mathrm{C}$ after $30 \mathrm{~min}$. These findings indicate that glucose(xylose) isomerase from Streptomyces sp. $\mathrm{CH} 7$ has the potential for industrial applications, especially for high-fructose syrup production and bioethanol fermentation from hemicellulosic hydrolysates by Saccharomyces cerevisiae.
\end{abstract}

Key words: agricultural residues, glucose(xylose) isomerase, production, purification, Streptomyces

\section{INTRODUCTION}

Glucose(xylose) isomerase catalyzes the reversible isomerization of glucose to fructose and that of xylose to xylulose. It is an important enzyme used in the industrial production of high-fructose corn syrup (HFCS) (3). Apart from the food industry, this enzyme has recently gained more interest due to its potential applications in the biofuel industry. Currently, ethanol is the major form of biofuel, and numerous technologies have been employed to improve its production (1, 19, 26). Furthermore, fuel ethanol production from hemicellulosic hydrolysates by Saccharomyces cerevisiae is of great economic interest as an alternative to fossil fuel (18). Whereas wild-type $S$. cerevisiae can ferment xylulose to ethanol via the pentose-phosphate pathway (28), it cannot ferment xylose. Xylose is a major monosaccharide in plant hemicellulosic hydrolysates that can account for up to $30 \%$ of total sugars in some plant biomasses such as that of hardwoods 
and agricultural residues (8). Therefore, glucose(xylose) isomerase indirectly plays an important role in the ethanol fermentation of plant biomass hydrolysates by $S$. cerevisiae.

Many microorganisms have been reported to produce glucose isomerase, and most of them require xylose as an inducer for enzyme synthesis $(2,6,9)$. Hemicelluloses are heterogeneous plant polymers consisting of pentoses, hexoses and sugar acids in which xylan, a backbone of 1,4-linked xylopyranosyl residues, is found as the major polymeric compound (28). As hemicelluloses are abundantly available in nature, they are good renewable resources for biofuel production, and they are cheap substrates for the production of glucose isomerase by microorganisms capable of growing on xylan-containing materials. We previously reported that Streptomyces sp. $\mathrm{CH} 7$ is capable of growing on xylan and that it efficiently produces $\beta$-xylosidase $(20,27)$. Furthermore, we also showed that $\beta$-xylosidase from this strain acts cooperatively with other xylanolytic enzymes from Streptomyces sp. PC22 to efficiently hydrolyze agricultural residues simply prepared as milled particles with no requirement for prior pretreatment with either chemicals or steam explosion (21). Here we report the ability of Streptomyces sp. $\mathrm{CH} 7$ to produce glucose isomerase when grown on agricultural residues. The ability of Streptomyces sp. $\mathrm{CH} 7$ to use low cost substrates for glucose isomerase production will reduce enzyme production costs and subsequently make both HFCS and ethanol production from hemicellulosic hydrolysates more cost effective and sustainable. The purification and characterization of this enzyme are also presented.

\section{MATERIALS AND METHODS}

\section{Microorganism}

Streptomyces sp. CH7 (GenBank accession number DQ385868) was used. It was maintained as a spore suspension at $-20^{\circ} \mathrm{C}$ and prepared according to Kieser et al. (11).

\section{Growth conditions and enzyme preparation}

A seed culture was prepared by inoculating $100 \mu \mathrm{l}$ of spore suspension $\left(\sim 10^{8}\right.$ spores $\left.\mathrm{ml}^{-1}\right)$ into $30 \mathrm{ml}$ of Tryptic Soy Broth (TSB) adjusted to $\mathrm{pH} 7.0$ and incubated for $24 \mathrm{~h}$ with shaking at $200 \mathrm{rpm}$ and $40^{\circ} \mathrm{C}$. Ten percent $(\mathrm{v} / \mathrm{v})$ of the seed culture was inoculated into production medium described by Raweesri et al. (21) consisting of (w/v) 0.5\% polypeptone, $0.1 \%$ yeast extract, $\quad 0.4 \% \quad \mathrm{~K}_{2} \mathrm{HPO}_{4}, \quad 0.02 \% \quad \mathrm{KCl}, \quad 0.1 \%$ $\mathrm{MgSO}_{4} .7 \mathrm{H}_{2} \mathrm{O}$, and $0.002 \% \mathrm{FeSO}_{4} .7 \mathrm{H}_{2} \mathrm{O}$ but using xylose, oat spelt-xylan or agricultural residues (milled and sieved to approximately $200 \mu \mathrm{m}$-particle size) at the concentrations indicated in the results as a carbon source. The $\mathrm{pH}$ of the medium was adjusted to 7.0. After cultivation, mycelia were removed from the culture by centrifugation at $5000 \mathrm{rpm}$ for 20 min and washed twice with $50 \mathrm{mM}$ sodium phosphate buffer, $\mathrm{pH}$ 7.0. The culture supernatant was used to determine xylanase activity. Mycelial extract was prepared by permeabilizing the mycelia with detergent as described by D’Cunha (5) with some modifications. Briefly, mycelia were suspended in $0.1 \%$ cetyl trimethyl ammonium bromide $(\mathrm{CTAB})$ at a ratio of $1 \mathrm{ml}$ packed cells to $3 \mathrm{ml}$ of the CTAB solution, and permeabilization was carried out for $24 \mathrm{~h}$ at $40^{\circ} \mathrm{C}$. After removing cell debris by centrifugation at $10,000 \mathrm{xg}$ for $20 \mathrm{~min}$, the supernatant was used for the determination of Dglucose/D-xylose isomerase, $\beta$-xylosidase activities and protein content.

\section{Protein content}

Protein content was determined by the Lowry method (17) using bovine serum albumin as a standard.

\section{Enzyme assays}

D-Glucose isomerase was assayed in a reaction mixture that contained $0.5 \mathrm{M}$ D-glucose, $150 \mathrm{mM}$ sodium phosphate buffer, $\mathrm{pH}$ 7.0, $5 \mathrm{mM} \mathrm{MgSO}_{4}, 0.1 \mathrm{mM} \mathrm{CoCl}_{2}$ and enzyme solution in a final volume of $2 \mathrm{ml}$. After incubation at $85^{\circ} \mathrm{C}$ for $20 \mathrm{~min}$, the amount of fructose formed was determined by the cysteine-carbazole method (7). One unit (U) of enzyme activity 
was equal to the formation of $1 \mu \mathrm{mol}$ of fructose per min under the assay conditions employed. D-Xylose isomerase was assayed under the same conditions as those for D-glucose isomerase except that D-glucose was replaced by D-xylose and the product formed, D-xylulose, was determined by the same colorimetric assay. Xylanase activity was determined by measuring the release of reducing sugars from xylan as previously described (29). $\beta$-Xylosidase was determined by measuring the amount of $\mathrm{p}$-nitrophenol released from $\mathrm{p}$ nitrophenyl- $\beta-\mathrm{D}$-xylopyranoside as previously described (20).

\section{Purification of glucose isomerase}

The mycelial extract referred to as the crude enzyme from Streptomyces sp. $\mathrm{CH} 7$ was used for glucose isomerase purification. The crude enzyme was loaded onto a Macro-Prep DEAE ( Bio-Rad Laboratories ) column $(1.5 \times 30 \mathrm{~cm})$ and the bound protein was eluted with a linear gradient of $\mathrm{NaCl}(0-0.8$ $\mathrm{M})$ in $0.05 \mathrm{M}$ Tris- $\mathrm{HCl}$ buffer $(\mathrm{pH} 7.5)$ at a flow rate of $30 \mathrm{ml}$ $\mathrm{h}^{-1}$. The active fractions were pooled, concentrated by ultrafiltration using a $10 \mathrm{kDa}$-molecular weight cut-off membrane filter, - dialyzed against $50 \mathrm{mM}$ sodium phosphate buffer ( $\mathrm{pH} 7.0$ ) containing $5 \mathrm{mM} \mathrm{MgSO}_{4} \cdot 7 \mathrm{H}_{2} \mathrm{O}$ and $0.1 \mathrm{mM}$ $\mathrm{CoCl}_{2} .6 \mathrm{H}_{2} \mathrm{O} 2$ times and finally against the same buffer containing $30 \%(\mathrm{v} / \mathrm{v})$ glycerol. The concentrated solution was loaded onto a Sephacryl S-300 column $(1 \times 30 \mathrm{~cm})$ previously equilibrated with $50 \mathrm{mM}$ sodium phosphate buffer $(\mathrm{pH} 7.0)$ containing $100 \mathrm{mM} \mathrm{NaCl}, 5 \mathrm{mM} \mathrm{MgSO} 4.7 \mathrm{H}_{2} \mathrm{O}$ and $0.1 \mathrm{mM}$ $\mathrm{CoCl}_{2} .6 \mathrm{H}_{2} \mathrm{O}$ and eluted with the same buffer at a flow rate of $15 \mathrm{ml} \mathrm{h}^{-1}$. The active fractions were pooled, concentrated, and glycerol was added to a final concentration of $20 \%(\mathrm{v} / \mathrm{v})$. The purified enzyme was kept at $-20^{\circ} \mathrm{C}$ for prolonged storage.

\section{Influence of temperature, $\mathrm{pH}$, metal ions and enzyme kinetics}

Glucose isomerase activity was determined under standard conditions except that different temperatures were assayed within the range $35-90^{\circ} \mathrm{C}$. The enzyme activity was then determined at various $\mathrm{pH}$ values ranging from 4.0 to 9.0 at the predetermined optimal temperature. The thermostability of the enzyme was evaluated by measuring the residual activity after a 30 min pre-incubation of the enzyme in the absence of substrate at various temperatures between 35 and $90{ }^{\circ} \mathrm{C}$, and $\mathrm{pH}$ stability was studied by pre-incubating the enzyme in the presence of substrate at pHs ranging from 4.0 to 9.0 at $85^{\circ} \mathrm{C}$ for $30 \mathrm{~min}$ and assaying the remaining enzymatic activity under standard conditions.

For the influence of metal ions, the enzyme was pretreated with EDTA by dialyzing overnight against $100 \mathrm{mM}$ EDTA in $50 \mathrm{mM}$ sodium phosphate buffer ( $\mathrm{pH} 7.0)$, and after that it was dialyzed twice against the same buffer without EDTA. The effect of metal ions was assessed by pre-incubating the enzyme with the test compound at $0{ }^{\circ} \mathrm{C}$ for $30 \mathrm{~min}$ and then assaying the residual enzymatic activity under standard conditions. The Michaelis-Menten kinetic parameters $K_{m}$ and $V_{\max }$ were determined from Lineweaver-Burk plots using glucose and xylose at concentrations ranging from 100 to $800 \mathrm{mM}$ and 20 to $160 \mathrm{mM}$, respectively, as substrate.

\section{Estimation of molecular mass}

The apparent molecular mass of the purified enzyme in native form was determined by gel filtration on Sephacryl S300 using ferritin $(450 \mathrm{kDa})$, catalase $(250 \mathrm{kDa})$ and globulin $(150 \mathrm{kDa})$ as molecular mass standards. Subunit molecular masses were determined by sodium dodecyl sulfatepolyacrylamide gel electrophoresis (SDS-PAGE) in a $12 \%$ (w/v) acrylamide gel by the method of Laemmli (13).

\section{RESULTS AND DISCUSSION}

\section{Effects of xylose and glucose on glucose isomerase production}

The present work demonstrated that Streptomyces sp. CH7 is capable of producing glucose isomerase when grown on either xylose or glucose (Fig. 1). Enzyme activity was roughly five-fold higher in the presence of xylose, indicating that the synthesis of this enzyme is constitutive in the presence of 
glucose and inducible by xylose. The constitutive biosynthesis of this enzyme by $\mathrm{CH} 7$ is similar to that of Arthrobacter nicotianae reported recently by Sapunova et al. (25). However, the glucose isomerase producing ability of $\mathrm{CH} 7$ is different from that of either Streptomyces sp. EC10 (2) (in which no enzyme activity is detected when grown on glucose) or Arthrobacter ureafaciens (24) (in which glucose inhibits enzyme synthesis when grown on xylose). A glucose isomerase activity level of about $1.8 \mathrm{U} / \mathrm{mg}$ of protein was obtained from $\mathrm{CH} 7$ when grown on $1 \%$ xylose, which is quite high compared to Arthrobacter nicotianae (0.5 U/mg), E. coli $(0.5 \mathrm{U} / \mathrm{mg})$ and Erwinia carotovora subsp. Atroseptica $(0.8$ $\mathrm{U} / \mathrm{mg}$ ) (23) grown on the same concentration of xylose. At $0.5 \%$ xylose, $\mathrm{CH} 7$ produced roughly $0.8 \mathrm{U} / \mathrm{mg}$ of enzyme, which is still higher than Bacillus thermoantarcticus (0.18 U/mg) (14) and Arthrobacter ureafaciens (0.06 U/mg) (24) grown on the same concentration of xylose. Therefore, Streptomyces sp. CH7 is a strong glucose isomerase producer and an attractive candidate for industrial applications.

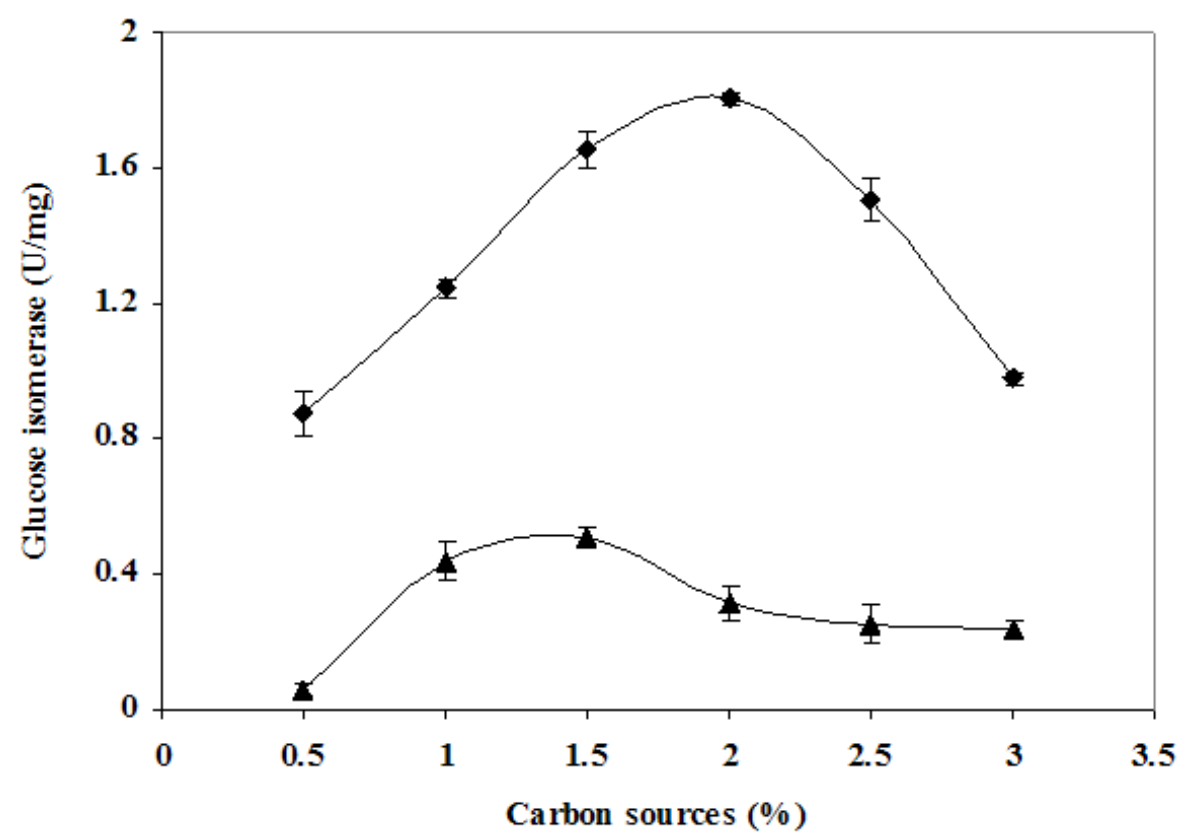

Figure 1. Effects of glucose $(\boldsymbol{\Delta})$ and xylose ( $)$ on glucose isomerase production by Streptomyces sp. $\mathrm{CH} 7 \mathrm{cultivated}$ at $40^{\circ} \mathrm{C}$ with shaking at $200 \mathrm{rpm}$ for 24 hours.

Effects of xylan and agricultural residues on glucose isomerase production

Because $\mathrm{CH} 7$ can grow on xylan and produce $\beta$ xylosidase (20), we investigated its ability to produce glucose isomerase when grown on xylan. As shown in Figure 2, $\mathrm{CH} 7$ efficiently produced the enzyme in the presence of xylan. This capability will lead to the discontinuation of xylose as an inducer. The maximum glucose isomerase production (of about $5 \mathrm{U} / \mathrm{mg}$ ) was obtained at $1 \%$ xylan when grown for 3 days. The enzymatic activity was about 3-fold higher when xylan was used as the carbon source as compared with the use of xylose as a carbon source. This finding is in agreement with those of Belfaquih and Penninckh (2) who studied Streptomyces sp. EC10 and found that higher levels of xylose isomerase were produced using xylan, from either birchwood or oat-spelt, as the carbon source than was produced using xylose as the carbon source. Streptomyces sp. EC10 provided roughly 1.3and 1.7-fold higher enzyme levels with xylan from oat-spelt and birchwood, respectively.

We further investigated the ability of $\mathrm{CH} 7$ to use different hemicellulosic agricultural residues as a carbon source for the simultaneous production of xylanolytic enzymes including 
xylanase, $\beta$-xylosidase and glucose isomerase. The results shown in Table 1 indicate that corn husks are the best carbon source for enzyme production, and the optimal concentration of corn husks is shown in Figure 3. This finding shows that cheap and abundantly available agricultural residues can replace the more expensive xylose and xylan for glucose isomerase production by $\mathrm{CH} 7$.

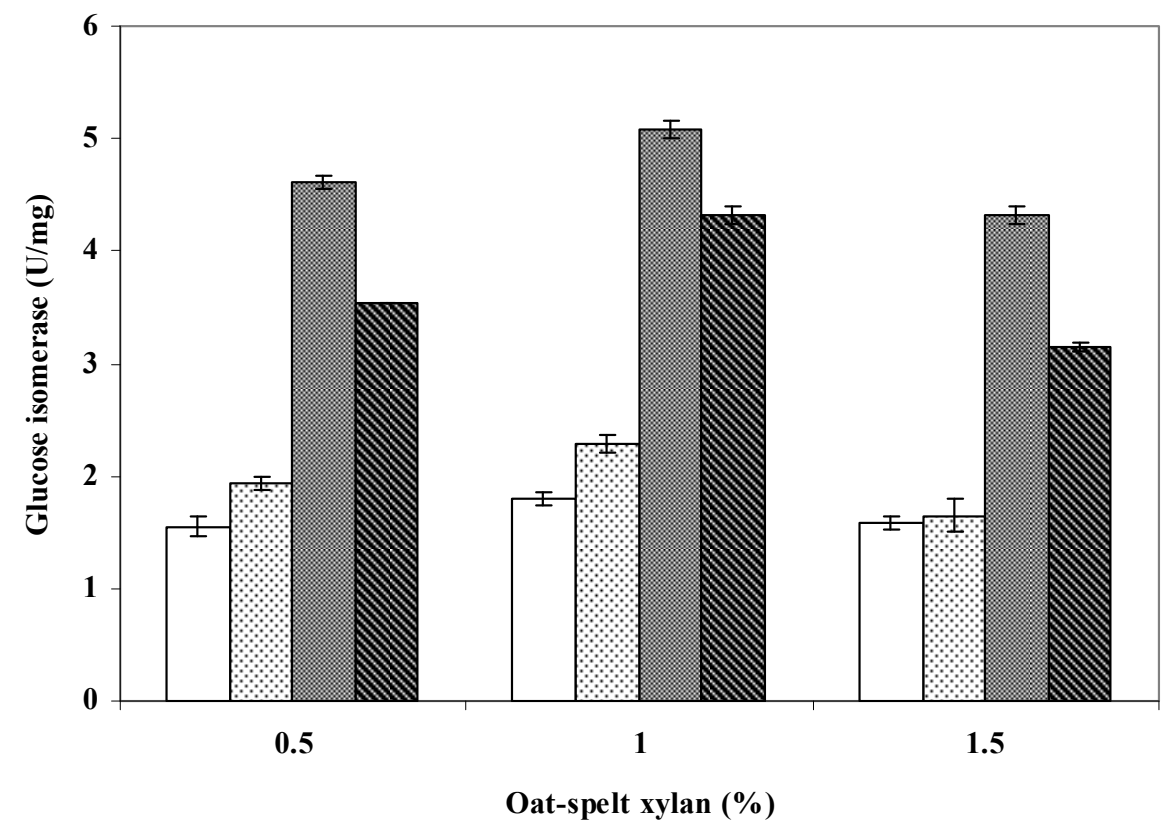

Figure 2. Effect of oat-spelt xylan on glucose isomerase production by Streptomyces sp. $\mathrm{CH} 7$ grown at $40^{\circ} \mathrm{C}$ with shaking at 200

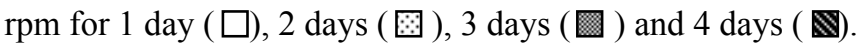

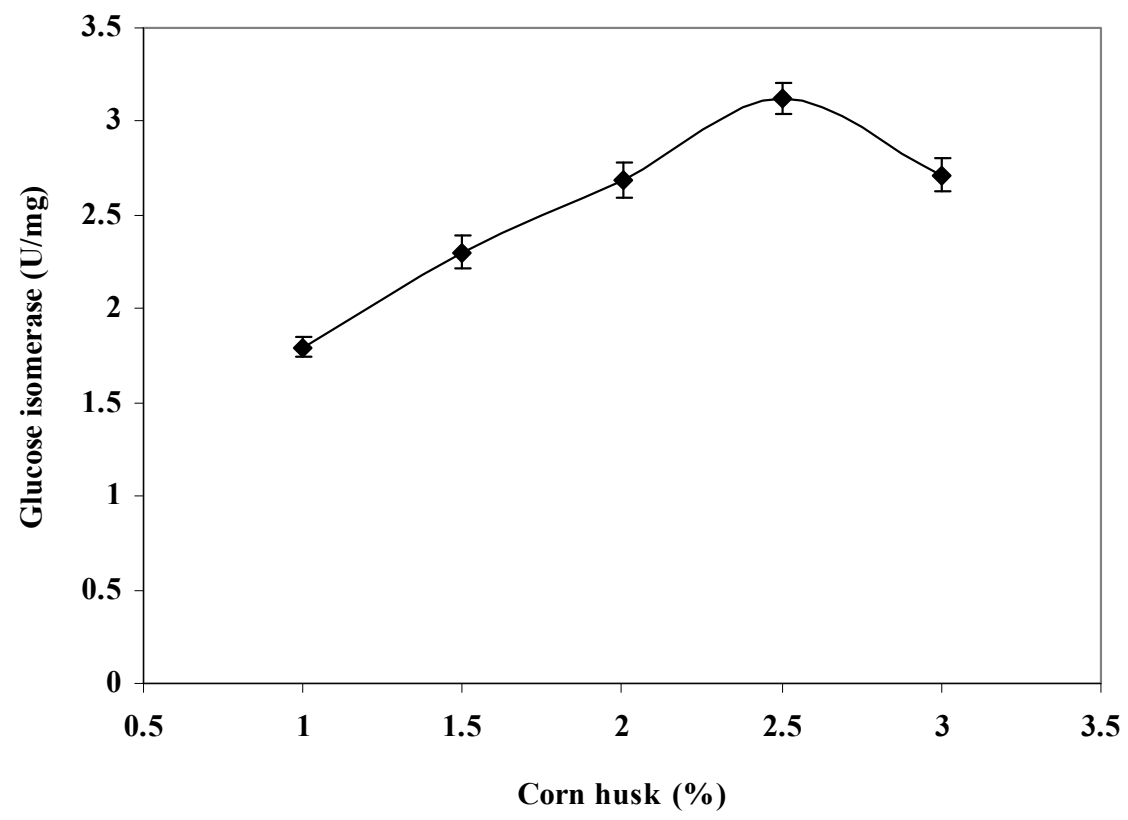

Figure 3. Effect of concentrations of corn husk on glucose isomerase production by Streptomyces sp. CH7 grown for 3 days. 
Table 1. Effect of different hemicellulosic agricultural residues $(1 \%, w / v)$ on the production of xylanase, $\beta$-xylosidase and glucose isomerase by Streptomyces sp. $\mathrm{CH} 7$ grown for 3 days.

\begin{tabular}{cccc}
\hline Carbon sources & $\begin{array}{c}\text { Glucose Isomerase } \\
(\mathbf{U} / \mathbf{m g})\end{array}$ & $\begin{array}{c}\text { Xylanase } \\
(\mathbf{U} / \mathbf{m l})\end{array}$ & $\begin{array}{c}\boldsymbol{\beta} \text {-Xylosidase } \\
\mathbf{( U / m g )}\end{array}$ \\
\hline corn cob & $1.45 \pm 0.02$ & $0.13 \pm 0.01$ & $0.37 \pm 0.01$ \\
corn husk & $1.85 \pm 0.02$ & $0.23 \pm 0.01$ & $0.49 \pm 0.02$ \\
cotton seed husk & $0.41 \pm 0.09$ & $0.11 \pm 0.03$ & $0.37 \pm 0.03$ \\
rice bran & $0.41 \pm 0.02$ & $0.06 \pm 0.01$ & $0.14 \pm 0.11$ \\
wheat bran & $1.07 \pm 0.01$ & $0.49 \pm 0.08$ & $0.33 \pm 0.06$ \\
\hline
\end{tabular}

\section{Purification, molecular characteristics and properties of} glucose isomerase

Glucose isomerase from Streptomyces sp. CH7 was purified to homogeneity from the mycelial extract by only two column chromatography steps. A summary of the purification procedures is presented in Table 2. The final purification resulted in a considerably high yield (64.5\%) with about 16fold purity. The molecular mass of the enzyme was estimated by gel filtration on Sephacryl-300 to be approximately $170 \mathrm{kDa}$ (data not shown), and it consists of four identical subunits with a molecular mass of $43.6 \mathrm{kDa}$ as estimated by SDS-PAGE (Fig 4). These values are slightly different from those of the glucose isomerases from Streptomyces sp. EC10 (163 kDa with 4 identical subunits of $42 \mathrm{kDa}$ ) (2) and from Streptomyces sp. SK strain (180 kDa with four 43-kDa subunits) (4).

As shown in Figure 5, the enzyme had maximal activity at $85^{\circ} \mathrm{C}$ and was still quite active at $90^{\circ} \mathrm{C}$. It was found to be stable at temperatures up to $60^{\circ} \mathrm{C}$ and to retain about $50 \%$ of its activity at $75^{\circ} \mathrm{C}$, but it completely lost activity at $80^{\circ} \mathrm{C}$. The thermostable properties of this enzyme are similar to those of other thermostable microorganisms including Thermoanaero bacterium strain JW/SL-YS $489 \quad$ (16), Bacillus thermoantarticus (14), E. coli K12 (22) and Thermus thermophilus (30); thus, it is a thermostable enzyme. Its optimal $\mathrm{pH}$ is 7.0 , and it is stable across a broad $\mathrm{pH}$ range (from 5.5 to 8.5 ) when tested by preincubating the enzyme in the absence of substrate at different $\mathrm{pH}$ values at $4^{\circ} \mathrm{C}$ for 30 $\min$ (Fig. 6).

Table 2. Summary of purification of glucose isomerase from Streptomyces sp. CH7.

\begin{tabular}{lccccc}
\hline \multicolumn{1}{c}{ Purification step } & $\begin{array}{c}\text { Total protein } \\
(\mathbf{m g})\end{array}$ & $\begin{array}{c}\text { Total } \\
\text { activity }(\mathbf{U})\end{array}$ & $\begin{array}{c}\text { Specific activity } \\
(\mathbf{U} / \mathbf{m g})\end{array}$ & $\begin{array}{c}\text { Yield } \\
(\mathbf{\%})\end{array}$ & $\begin{array}{c}\text { Purification } \\
\text { (fold) }\end{array}$ \\
\hline Crude extract & 34.2 & 92.8 & 2.71 & 100.0 & 1.0 \\
Macro-prep DEAE & 2.2 & 71.6 & 32.55 & 77.2 & 12.0 \\
Sephacryl S-300 & 1.4 & 59.9 & 42.78 & 64.5 & 15.9 \\
\hline
\end{tabular}

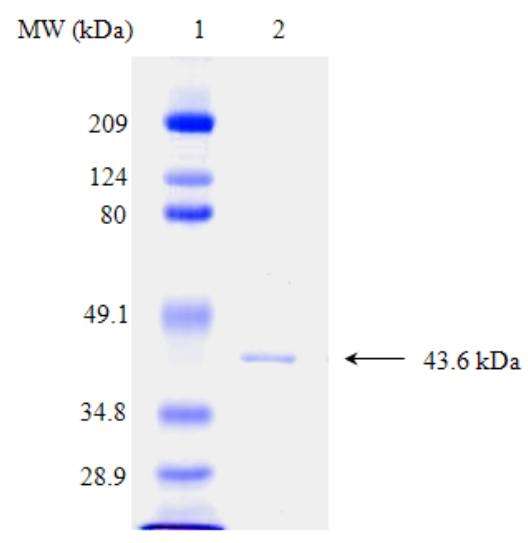

Figure 4. SDS-polyacrylamide gel electrophoresis of purified glucose isomerase. Lane 1, molecular mass standard; myosin (209 $\mathrm{kDa}), \beta$-galactosidase (124 kDa), bovine serum albumin (80 $\mathrm{kDa})$, ovalbumin $(49.1 \mathrm{kDa})$, carbonic anhydrase $(34.8 \mathrm{kDa})$, soy bean trypsin inhibitor $(28.9 \mathrm{kDa})$; Lane 2, purified glucose isomerase from Streptomyces $\mathrm{sp}$. CH7(1.4 $\mu \mathrm{g})$. 


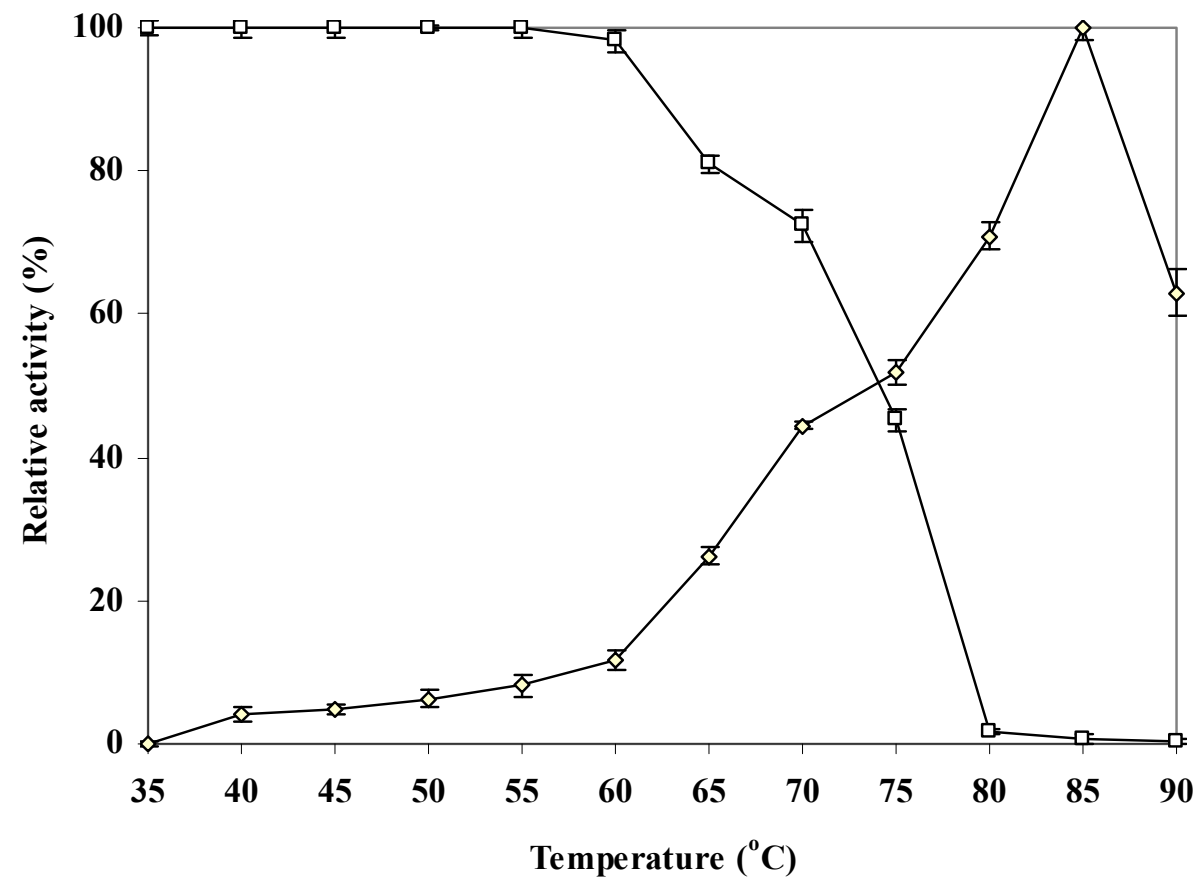

Figure 5. Effects of temperature on activity $(\diamond)$ and stability $(\square)$ of the enzyme.

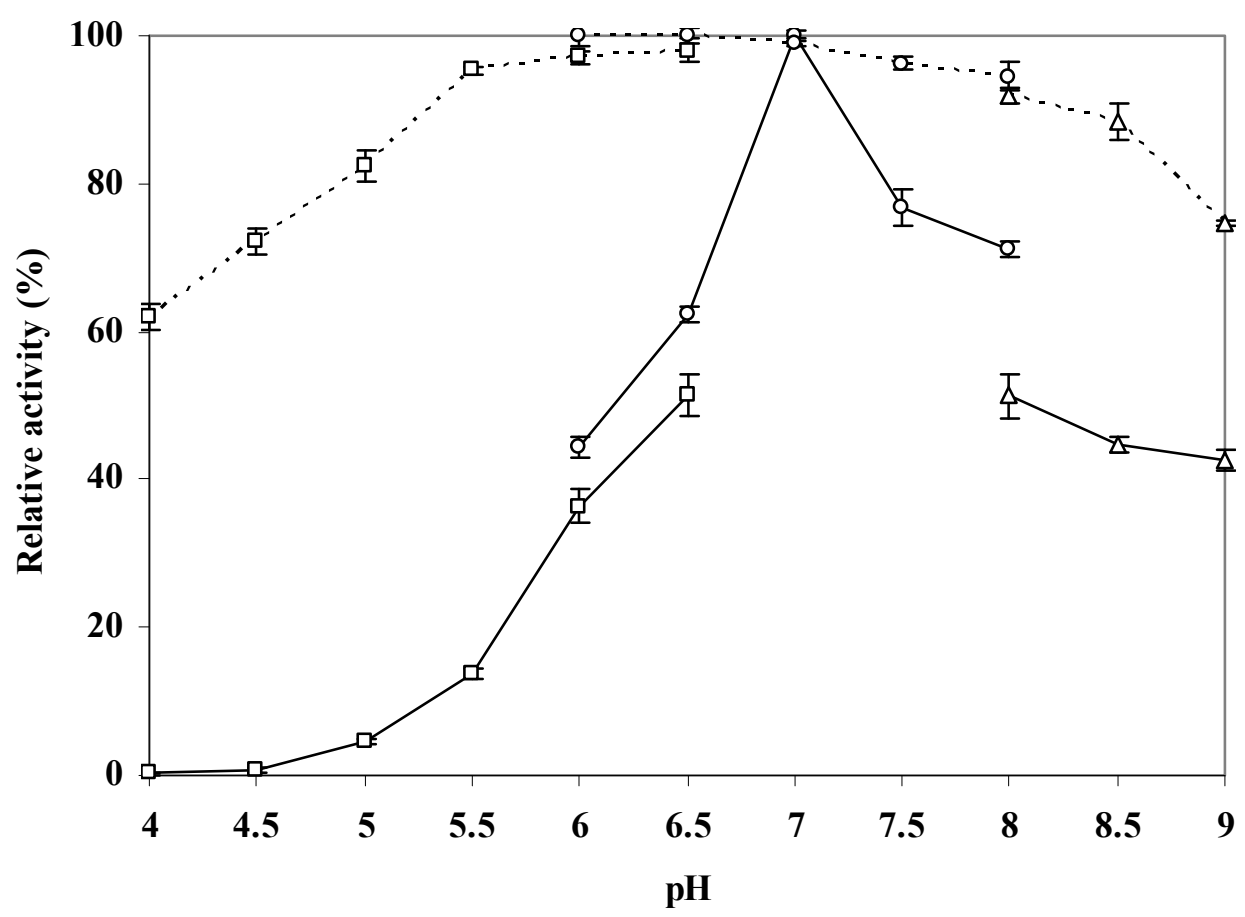

Figure 6. Effects of pH on activity ( $\longrightarrow$ ) and stability (_ . ) of the enzyme. ( $\square$ ), $100 \mathrm{mM}$ acetate buffer; ( $\mathrm{O}$ ), $100 \mathrm{mM}$ phosphate buffer; $(\triangle), 100 \mathrm{mM}$ Tris-HCl buffer. 
Regarding substrate specificity, under standard assay conditions the Michealis-Menten constant $\left(K_{\mathrm{m}}\right)$ values of the enzyme for glucose and xylose were found to be 258.96 and $82.77 \mathrm{mM}$, respectively, and the $\mathrm{V}_{\max }$ values were 32.42 and $63.64 \mu \mathrm{M} / \mathrm{min} / \mathrm{mg}$, respectively. The lower $K_{\mathrm{m}}$ values for xylose, as compared to glucose, indicates that this glucose isomerase has a preference for xylose as a substrate over glucose, which is in agreement with glucose isomerases from other microorganisms. However, its $K_{\mathrm{m}}$ values for both substrates were found to be lower than those of Bacillus sp. Tx3 ( $K_{\mathrm{m}}$ values of 290 and $100 \mathrm{mM}$ for glucose and xylose, respectively) whereas its $V_{\max }$ values are higher $\left(\mathrm{V}_{\max }\right.$ values of 1.6 and $28.6 \mu \mathrm{M} / \mathrm{min} / \mathrm{mg}$ for glucose and xylose, respectively) (12). Its $K_{\mathrm{m}}$ value for glucose is lower than that of Streptomyces sp. PLC (400 mM), but for xylose it is slightly higher (35 mM) (10). Due to its preference for xylose and its lower $K_{\mathrm{m}}$ value for glucose when compared to those of the other strains mentioned above, glucose isomerase from $\mathrm{CH} 7$ has the potential for industrial applications such as highfructose syrup production and xylose isomerization for substrate preparation for ethanol fermentation by $S$. cerevisiae. It was also found that this enzyme has no activity against $\beta$-Dxylopyranoside, which distinguishes it from glucose isomerase from Streptomyces sp. EC10 (2) and indicates that it is not a bifunctional $\beta$-xylosidase/ xylose isomerase protein.

\section{Effect of metal ions}

There have been reports that glucose isomerases typically require divalent metal ions such as $\mathrm{Mg}^{2+}, \mathrm{Co}^{2+}$ or $\mathrm{Mn}^{2+}$ as cofactors $(14,15)$. Glucose isomerase from Streptomyces sp. $\mathrm{CH} 7$ was found to be similar to the enzyme from Bacillus thermoantarcticus (14), for which the combination of $\mathrm{Mg}^{2+}$ and $\mathrm{Co}^{2+}$ is essential for enzymatic activity. However, the enzyme from Streptomyces sp. $\mathrm{CH} 7$ reached maximum activity at 10 $\mathrm{mM} \mathrm{Mg}^{2+}$ and $0.1 \mathrm{mM} \mathrm{Co}^{2+}$ (Table 3), whereas that of $B$. thermoantarcticus requires a much higher $\mathrm{Co}^{2+}$ concentration ( $1 \mathrm{mM}$ ) but the same $\mathrm{Mg}^{2+}$ concentration. Because $\mathrm{Co}^{2+}$ is a heavy and toxic metal ion, glucose isomerase from $\mathrm{CH} 7$ has superior properties because it needs only a trace amount of $\mathrm{Co}^{2+}$ for its optimal activity.

Table 3. Effect of metal ions on activity of EDTA-treated glucose isomerase from Streptomyces sp CH7.

\begin{tabular}{|c|c|}
\hline Metal & Relative activity (fold) \\
\hline No metal added & 1.0 \\
\hline $\mathrm{Mg}^{2+}(1.0 \mathrm{mM})$ & 3.6 \\
\hline $\mathrm{Mn}^{2+}(1.0 \mathrm{mM})$ & 2.8 \\
\hline $\mathrm{Ca}^{2+}(1.0 \mathrm{mM})$ & 2.5 \\
\hline $\mathrm{Fe}^{2+}(1.0 \mathrm{mM})$ & 0.1 \\
\hline $\mathrm{Co}^{2+}(1.0 \mathrm{mM})$ & 2.1 \\
\hline $\mathrm{Co}^{2+}(0.1 \mathrm{mM})$ & 4.4 \\
\hline $\mathrm{Mg}^{2+}(1.0 \mathrm{mM})+\mathrm{Co}^{2+}(0.1 \mathrm{mM})$ & 6.2 \\
\hline $\mathrm{Mg}^{2+}(5.0 \mathrm{mM})+\mathrm{Co}^{2+}(0.1 \mathrm{mM})$ & 26.5 \\
\hline $\mathrm{Mg}^{2+}(10.0 \mathrm{mM})+\mathrm{Co}^{2+}(0.1 \mathrm{mM})$ & 44.2 \\
\hline $\mathrm{Mg}^{2+}(15.0 \mathrm{mM})+\mathrm{Co}^{2+}(0.1 \mathrm{mM})$ & 23.3 \\
\hline
\end{tabular}

\section{CONCLUSION}

Streptomyces sp. $\mathrm{CH} 7$ was found to be capable of producing glucose(xylose) isomerase efficiently when grown in medium containing corn husks, simply prepared as milled particles, as a carbon source. This cheap and abundantly available carbon source will result in low enzyme production costs. The enzyme was found to have optimal activity at $85^{\circ} \mathrm{C}$ and $\mathrm{pH}$ 7.0, and it is stable across a broad $\mathrm{pH}$ range (5.5-8.5). Therefore, it has the potential for industrial applications, especially for high-fructose syrup production and for substrate preparation for bioethanol fermentation from xylose (a major 
component in hemicellulosic hydrolysates) by Saccharomyces cerevisiae.

\section{ACKNOWLEDGEMENTS}

This work was supported in part by CU.GRADUATE SCHOOL THESIS GRANT, Chulalongkorn University, Thailand.

\section{REFERENCES}

1. Bangrak, P.; Limtong, S.; Phisalaphong, M. (2011). Continuous ethanol production using immobilized yeast cells entrapped in loofa-reinforced alginate carriers. Braz. J. Microbiol. 42(2):676-684.

2. Belfaquih, N.; Penninckx, M.J. (2000). A bifunctional $\beta$-xylosidasexylose isomerase from Streptomyces sp. EC10. Enzyme Microl. Technol. 27:114-121.

3. Bhosale, S.H.; Rao, M.B.; Deshpande, V.V. (1996). Molecular and industrial aspects of glucose isomerase. Microbiol. Rev. 60:280-300.

4. Borgi, M.A.; Srih-Belguith, K.; Ali, M.B.; Mezghani, M.; Tranier, S.; Haser, R.; Bejar, S. (2004). Glucose isomerase of the Streptomyces sp. SK strain : purification, sequence analysis and implication of alanine 103 residue in the enzyme thermostability and acidotolerance. Biochimie. $86: 561-568$

5. D'Cunha, G.B. (2005). Enrichment of phenylalanine ammonia lyase of Rhodotolura yeast. Enzyme and Microb.Tech. 36:498-502.

6. Deshmukh, S.S.; Deshpande, M.V.; Shankar, V. (1994). Medium optimization for the production of glucose isomerase from thermophilic Streptomyces thermonitrificans. World. J. Microbiol. Biotechnol. 10:264-267.

7. Dische, Z.; Borenfreund, E. (1951). A new spectrophotometric method for the detection of keto sugar trioses. J. Biol. Chem. 192:583-587.

8. Ericksson, K. E. L.; Blanchette, R. A.; Ander, P. (1990). Microbial and enzymatic degradation of wood and wood components. pp. 181-222. Ozach GmbH and Co., Berlin, Germany.

9. Givry, S.; Duchiron, F. (2007). Optimization of culture medium and growth conditions for production of L-arabinose isomerase and D-xylose isomerase by Lactobacillus bifermentans. Microbiology. 77(3):281-287.

10. Inyang, C.U.; Gebhart, U.; Obi, S.K.C.; Bisswanger, H. (1995). Isolation and characterization of a D-glucose/xylose isomerase from a new thermophilic strain Streptomyces sp. PLC. Appl. Microbiol. Biotechnol. 43: $632-638$.

11. Kieser, T.; Bibb, M.J.; Buttner, M.; Chater, K.F.; Hopwood, D.A. (2000). Practical Streptomyces genetics. pp. 43-47. The Jonh Innes Foundation, Jonh Innes Centre, Norwich, England.
12. Kitada, M.; Dobashi, Y.; Horikoshi, K. (1989). Enzymatic properties of purified D-xylose isomerase from a thermophilic alkalophile, Bacillus TX-3. Agric. Biol. Chem. 53(6): 1461-1468.

13. Laemmli, U. K. (1970). Cleavage of structural proteins during the assembly of the head of bacteriophage T4. Nature. 227:680-685.

14. Lama, L.; Nicolaus, B.; Calandrelli, V.; Romano, I.; Basile, R.; Gambacorta, A. (2001). Purification and characterization of thermostable xylose(glucose) isomerase from Bacillus thermoantarcticus. J. Ind. Microbiol. Biotecnol. 27:234-240.

15. Lehmacher, A.; Bisswangher, H. (1990). Isolation and characterization of an extremely thermostable D-xylose isomerase from Thermus aquaticus HB8. J. Gen. Microbiol. 136:679-686.

16. Liu, S.Y.; Wiegel, J.; Gherardine, F.C. (1996). Purification and cloning of a thermostable xylose(glucose) isomerase with an acidic $\mathrm{pH}$ optimum from Thermoanaerobacterium sp. JW/SL-YS 489. J. Bacteriol. 178:5938-5945.

17. Lowry, O. H.; Rosebrough, N. J.; Farr, A. L.; Randall, R. J. (1951). Protein measurement with the folin phenol reagent. J. Biol. Chem. 193:267-275.

18. Mabee, W.E. (2007). Policy options to support biofuel production. Adv. Biochem. Eng. Biotechnol. 108:329-357.

19. Mohammadi, A.; Razavi, S.H.; Mousavi, S.M.; Rezaei, K. (2011). A comparative between sugar consumption and ethanol production in wort by immobilized Saccharomyces cerevisiae, Saccharomyces ludwigii and Saccharomyces rouxii on brewer's spent grain. Braz. J. Microbiol. 42(2):605-615.

20. Pinphanichakarn, P.; Tangsakul, T.; Thongnumwon, T.; Talawanich, Y.; Thamchaipenet, A. (2004). Purification and characterization of $\beta$ xylosidase from Streptomyces sp. $\mathrm{CH} 7$ and its gene sequence analysis. World. J. Microbiol. Biotechnol. 20:727-733.

21. Raweesri, P.; Riangrungrojana, P.; Pinphanichakarn, P. (2008). $\alpha$-LArabinofuranosidase from Streptomyces sp. PC22: purification, characterization and its synergistic action with xylanolytic enzymes in the degradation of xylan and agricultural residues. Biol. Technol. 99:8981-8986.

22. Rozanov, A.S.; Zagrebelny, S.N.; Beklemishev, A.B. (2009). Cloning of Escherichia coli K12 xylose isomerase(glucose isomerase) gene and studying the enzymatic properties of its expression product. Appl. Biochem. Microbiol. 45(1): 38-44.

23. Sapunova, L.I.; Lobanok, A.G.; Kazakevich, I.O.; Shlyakhotko, E.A.; Evtushenkov, A.N. (2006). Biosynthetic features and properties of xylose isomerases from Arthrobacter nicotianae, Escherichia coli, and Erwinia carotovora subsp. Atroseptic. Appl. Microbiol. Biotechnol. 42(3):246-251.

24. Sapunova, L.I.; Tamkovich, I.O.; Lobanok, A.G. (2008). Catabolite repression of xylose isomerase synthesis in Arthrobacter ureafaciens. Microbiology. 77(3):268-274. 
25. Sapunova, L.I.; Tamkovich, I.O.; Lobanok, A.G. (2010). Some aspects of xylose isomerase constitutive biosynthesis in Arthrobacter nicotianae. Appl. Biochem. Microbiol. 46(4): 438-442.

26. Tao, N.G.; Gao, Y.M.; Liu, Y.J. (2011). Isolation and characterization of a Pichia anomala strain: a promising candidate for bioethanol production. Braz. J. Microbiol. 42(2):668-675.

27. Ungchaithum, S.; Pinphanichakarn, P. (1998). Optimization of xylanase production by Streptomyces sp. PC22 growing on agricultural residues. J. Sci. Res. Chula. Univ. 23(1):45-50.

28. van Maris, A.J.A.; Abbott, D.A.; Bellissimi, E.; van den Brink, J.;
Kuyper, M.; Luttik, M.A.H.; Wisselink, H.W.; Scheffers, W.A.; van Dijken, J.P.; Promk, J.T. (2006). Alcoholic fermentation of carbon sources in biomass hydrolysates by Saccharomyces cerevisiae: current status. Antonie van Leeuwenhoek. 90:391-418.

29. Wateewuthajarn, K.; Pinphanichakarn, P. (2000). Purification and characterization of xylanase from Streptomyces sp. PC22. J. Sci. Res. Chula. Univ. 25(2):245-256.

30. Xu, W.; Yan, M.; Xu, L.; Ding, L.; Ouyang, P. (2009). Engineering the activity of thermophillic xylose isomerase by site-directed mutation at subunit interfaces. Enz. Microb. Tech. 44: 77-83. 